public? Are there not men connected with our (ours only) profession anxious and willing to undertake the most troublesome and responsible appointments gratuitously? Those so accepting appointments to hospitals and dispensaries have a hope thereby of getting a name and practice, but what can justify the folly of men advertising their gratuitous services to shipowners, knowing, as they must, that the law requires emigrant ships going to certain parts of the world, to take surgeons, and prevents their weighing anchor without one? Here is one of the very few instances in which the laws of our country protect or offer any encouragement to our profession; and yet her own members are so lost to the general interest, that to serve some selfish purpose, they contravene the law, and set the whole body, as it were, a-begging. Would it not be more respectable for those men who go hat in hand to the counting-houses of shipowners, offering their services for free passages to Australia, to pay their own fare, even in the lowest class, than to destroy that which might be made a useful, and moderately -remunerative employment to some hundreds of the profession? Why should we be the only professional men giving their services for nought; as you justly remarked, the clergyman, though he ought to be supposed to enter the Church for spiritual motives only, is not expected to attend to soul-saving without being paid; yet medical men offer theirs in preserving life. Why the hospital porter and cuddy servant are more alive to the interest of their class.

Surgeons accepted by shipowners, because offering their services gratuitous!y, cannot stand high in the estimation of their employers. Would not any rational man think that services offered for nothing are scarce worth having? So with the shipowner and surgeon : the former accepts the latter, not for his worth, but on account of the money he saves him, not caring whether he be competent or well-conducted, although in their advertisements about the sailing of ships, the recommendation of having an experienced surgeon is held out to the passengers; the owners, or charterers, are indifferent about the respectability or competency of the individual, so that he be (what the law requires) in possession of a diploma, leaving the poor passengers to find out during the voyage that their experienced gratis-working surgeon turns out to be an ignorant drunkard. Few such, it is to be hoped, are to be found in the profession, but all must admit that some are to be found amongst us; and who is so likely to offer himself for nought to the shipowner, who will ask but few questions, and supply plenty of lush? It is bad enough to have a trader in drugs announce that he can provide surgeons at twenty-four hours' notice, with the addition of a testimonial of competency from himself, but far worse is it to hear of the set of men who beg appointments at the shipowners and agents' counting-houses, and to hear shipowners talk of a gratuity of $£ 20$ for the voyage to Australia, when they require an extra decent fellow.

Can it be that the example set by the hospital and dispensary medical men in giving their services for nothing is followed by the juniors wishing to go to sea? As great men despise large rewards, so little men despise small rewards.

It is to be hoped, Sir, that as your journal so well advocates the well-being of the profession generally, you will find time to wake it to its own interest as regards emigration. That which would employ and benefit the juniors must also benefit the seniors. Emigration might employ hundreds annually, and thereby assist in doing away with the shabby trading which all must regret exists in the profession, which is overstocked. Teach the wouldbe emigrant surgcon what he ought to expect and insist on, as you have the naval and hospital men, as also the referees to insurance offices, and you will soon do a way with gratuitous worksuch remuneration as is advertised by the Central London School, (Times, Sept. 6th,) as also shipowners talking of gratuity to men whose services they cannot and must not dispense with. You will then more than ever deserve the thanks of the profession, including

September, 1852

Your obedient servant,

M. S.

\section{SHIP SURGEONS.}

TREATMENT OF SURGEONS OF EAST INDIA COMPANY'S SHIPS.

\section{To the Editor of The Lancet.}

SIR,-Permit me to address a few lines to you on a subject which, though of considerable moment, has not yet occupied your columns. I refer especially to the iliberality and injustice usually practised towards ship surgeons. It is, $I$ apprehend, one of the conditions of modern conventionalism, that this class of men, though holding a position involving more real responsibility than any equal number of junior members of the profession, should be regarded as ignorant, uneducated, and unworthy of gentlemanly treatment. It is hardly worth while to enlarge upon the inadequate remuneration which they receive, as the disgraceful awards made by the public to the time, labour, and skill of medical men are so often the theme of your just censure. I wish to direct your attention to a system practised by some shipowners, which, though not legally fraudulent, in the abstract is most strictly so. Most of your readers are probably not aware that the Indiamen belonging to our large firms are most generally employed by the East India Company for the transport of troops, invalid and otherwise, (as the case may be,) to England. Further, that the Company give a gratuity to the surgeon, of fifteen shillings a head for every man and woman landed, and ten shillings for every child, provided that the treatment of the medical man in charge shall appear to have been satisfactory to the proper authorities in England. This is technically termed "head money, and is intended by the Company as a remuneration to the surgeon for the increased trouble and anxiety which thus devolve upon him, as well, no doubt, as an efficient stimulus to exertion. And a liberal remuneration it is, were the surgeon permitted to receive it. But what is the system? The surgeon, on applying to the owners for employment, is compelled either to sign an agreement consigning the whole of the head money to the principals, and resigning all interest in it whatever, or-sad alternative - to go about his business forth with. Appended to this document is, generally, a saving clause, stating that he will be dependent wholly upon their generosity, or liberality, or some such misnomer. Again: on the vessel arriving in England, the surgeon is obliged, before receiving the pay due to him from the ship, to sign a document, authorizing the owners to receive the amount of head money. Frequently, also, the surgeon is put to considerable expense by remaining in Londov, in order to obtain the documents necessary to the passage of the accounts at the India House; but he looks in vain to be reimbursed.

It is useless to comment upon the injustice and nefarious character of these transactions; but the remedy I shall propose is this-that the East India Company peremptorily refuse to pay over the head money into the owners' hands, and even to the surgeon himself, unless he adduce satisfactory proof that he neither has been, nor will be, a party to its transference into other hands.

The sanguine hope that I entertain, that this abuse, exposed through the medium of your columns, will be reformed, has induced me to trespass thus far upon your space.

September, 1852 . remain, Sir, your obedient servant,

\section{THE C OLI E G E F L L O W S H P.} To the Editor of The LaNceT.

SIR,-Concurring entirely in your correspondent's (A. P. C.) letter, concerning the new batch of Fellows, may $I$ be allowed to inform him, that the public actually entertain the opinion that the "distinction" obtained by ten guineas and an old diploma is more honourable to the profession than the same rank earned by anxious study. The motive of the College in admitting Fellows upon such terms is worse than anomalous, for the regulations state, "that any member holding a diploma dated before Sept. 14, 1844 , can, after eight years," escape the preliminary examination. Therefore the hardship of getting up their classics and mathematics cannot be pleaded as an excuse for not submitting to an examination, by the fifty-five new Fellows.

Sept., 1852.

Your obedient servant,

\section{THE ABERDEEN UNIVERSITIES.}

\section{To the Editor of THE LaNcet.}

SIR,-I was a student in Arts and Medicine twelve years ago, both in the King's College and University, and in the Marischal College and University, Aberdeen.

The dispute concerning the legality of the latter in granting degrees, then occupied the leisure hours of the student, as it now occupies the leading columns of THe LANCET.

In their locality, both institutions are equally respected. Several of their professors and lecturers are men of more than average abilities, and the medical staff of the notable "Royal Infirmary" is selected from their number. I also know something regarding their examinations, and believe, that during the last fifteen years, the one in this respect is as rigid as the other.

Although neither Professors Clark or Fergusson are natives of the neighbourhood, yet, from the positions they hold in the rival colleges, they cannot fail to know that this unneigh. bourly dispute, divested of the "war of words," is of the usual 
nut-shell dimensions, and that after spelling through musty records, and translating half-obliterated charters, it simply resolves itself into this important fact-that the charter of King's College and University, specially expresses the authority of the "Senatus Academicus" to confer various degrees, while the charter of Marischal College and University only does so generally, as appertaining to a University.-I am, \&c.

London, Sept. 1852.

A. T. Ciralmers.

\section{OCCLUSION OF THE OS UTERI. [NOTE FROM DR. POWER.] \\ To the Editor of The Lancet.}

SIR,-Dr. Whitworth, in his communication to your journal on Saturday, September 4 th, has probably approximated to an explanation of Dr. Highmore's case of "occlusion of the os nteri," although the assumed principle of anteversion is in itself a supposition which requires further demonstration. The case in question admits of being referred to one of the sources of suspended labour so lately advocated by myself (see THE LANCET, July 24th, 1852 , p. 80 ), as dependent on an oblique position of the os uteri, and which may generally be regarded, not as the results of any accidental displacement of the body of the uterus itself, but of an original and permanent constitution of the organ, and hence the delay in the commencement of the labour has been repeated in the same patient. There is also some reason to regard this constitutional state as hereditary, inasmuch as some women suffer from it whose mothers had experienced apparently similar protractions in the early stages of their labours. In Dr. Highmore's case, I deem it probable that the os uteri was, on the principle described, turned obliquely backwards towards the promontory of the sacrum, so that the child's head pressed or gravitated downwards in the true axis of the pelvis, and formed a bulging tumour, protruding forwards more or less on the anterior parietes of the body of the uterus, so as to render it difficult with the finger to reach the os tincæ. The proper exciting stimn'us being thus taken off from the uterine orifice, the parturient action would be imperfectly elicited, and the early stage of the labour rendered tedious and inefficient; the os uteri would, however, in time, begin to dilate, and become more and more centrical; and in proportion as this takes place, the orificial irritation becomes more and more decided, and the action vigorous, eventually terminating the labour rapidly, as in Dr. Highmore's case.

Under such circumstances, I have always succeded in finding the os uteri, so as to be able to stimulate it and draw it into a more centrical position; and this with the effect of producing vigorous action and a rapid termination of the case.-I am, Sir, yours truly,

ennett-street, Sept. 1852. JoHN Power.

\section{THE MEDICAL PROFESSTON AND LIFE ASSURANCE OFFICES.}

WEST OF ENGLAND ASSURANCE COMPANY.

\section{To the Editor of THE LANCET.}

Srr,-About the 4 th of June Jast, I received a communication from the Secretary of the West of England Insurance Company, Exeter, enclosing the usual inquiries respecting a gentleman whom I atterided professionally, and whose life had been proposed for insurance in the above office. The gentleman referred to resided ten miles from me; and as I could not reply to the questions satisfactorily without a personal interview, I visited him for the express purpose, answered the questions, and returned them to the secretary, politely requesting a fee of one guinea for my trouble. A month having elapsed without any notice being taken of my note, I addressed a few lines to the secretary, remind. ing him of my former application,

In his reply of July 5 , he states that he regrets he cannot pay me a fee on behalf of the office, as it is not their custom, but refers me to the proposers of the insurance, enclosing their names and addresses. I immediately answered this by saying, that as I had no communication whatever with any other party but him. self, (the secretary of the company,) I must still consider that I was employed by the office, and that I could not think of applying to the proposers, who are perfect strangers to me; indeed, that I was of opinion that they, as well as my patient, would deem it a breach of confidence on the part of the office, in acquainting me with the circumstances, and that I must decline for the future filling up any printed forms without a suitable fee being enclosed. I also reminded him that I had been paid by their office, in two cases, under precisely similar circumstances, not many montlis before. This was again treated with silence, but on the 12th of August I received from the same office the usaal series of inquiries for the insurance of the life of another patient of mine.

I acknowledged the receipt of their favour, but referred their secretary to my former correspondence for the reasons why I could not return the form properly filled up.

I heard no more from the office, but accidentally learnt that their agents in this town had received instructions authorizing them to employ some other medical man to examine my patient, and pay him a fee on behalf of the company, as "they do not choose to be dictated to by any medical man."

It must be obvious, that without the evidence of the usual medical attendant, the returns must be very incomplete; and, however it may satisfy the present officials, the insurer who expects bonuses will find it prejudicial in the long run.

I think this subject requires no further comment on my part; I leave to you, Mr. Editor, and my professional brethren generally, to judge of the matter.

Would it not be advisable to republish a list of insurance offices who recognise the services of medical men?

I am, Sir, your obedient servant,

Sturminster-Newton, Dorset, JoHN GooD, M.R.C.S. \& L.A.C. Sept. 1852.

\section{CLOSURE OF THE RANELAGH SEWER.}

THE following statement regarding the Ranelagh sewer, signed by thirty-eight medical practitioners, has been forwarded to the Committee of the St. Paul and St. Barnabas Dispensary:-

"Genthemen,-We, the undersigned medical practitioners resident in Pimlico and Chelsea, having reason to believe that cholera will shortly make its appearance in our large towns, deem it our duty to recommend such means as experience has shown to be most successful in preventing its ravages.

"In the Report of the General Board of Health, July, 1849, it is stated, page 79 , that, " the attacks of cholera are uniformly found to be most frequent and virulent in low-lying districts, on the banks of rivers, in the neighbourhood of sewer-mouths, \&c.; and we are of opinion that open sewers are very prejudicial to health, as well as dangerous, in consequence of the accidents which occur from drowning.

"Permit us therefore respectfully to call your attention to the open condition of the Ranelagh sewer, which bounds, on one side, the district of the St. Paul and St. Barnabas Dispensary, and to hope that you will employ your utmost endeavour to remove the nuisance.

(Signed,)

"C.J. B. Alors, MID., 1, Chester-terrace, Chester-square. Wiluram Forwelu, M.R.C.S., 58, Upper Ebury street. John Perry, F.R.C.S., 4, Eaton-square.

Charles Whiting, M.R.C.S., 58, Upper Ebury-street. W. Batten, L.S.A., 74, Westbourne-street.

John Parr Scatifif, Surgeon, 47, Sloane-square.

John Halt, Surgeon, 47, Sloane-square.

W. M. Neale, Surgeon, 18, Westbourne-pl., Laton-sq. Robert Synnot, M.D., Surgeon, 16, Eaton-terrace.

Eoward Wrbb, M.R.C.S., Elizabeth-street, Eaton-sq. H. P. Banister, M.R.C.S., 65, Coleshill-street. G. A. Mantell, LL.D., F.K.S., Chester-square. W. P. Jondes, M.R.C.S., 14, Lower Belgrave-street. D. N. Frampton, 28, Lower Belgrave-street. J. W. Morey, M.R.C.S. Edin., L.A.C., 67, Up. Ebury-st. J. E. W. Rogers, M.R.C.S., L.A.C., 96 , Hugh-street. W. C. Meates, 41 , Chester-square.

J. S. Mackirtosn, Surgeon, 8, Wilton-place.

Alfred Leggats, ]3, William-street.

Edward Seaton, 33, Sloane-street.

James TeEvan, Surgeon, \&c., 30, Chesham-street. George C. Jonson, 1, Grosvenor-st. West, Eaton-sq. John Iree, M.R.C.S., 3, Lower-Grosvenor-place. Groram Vincent, M.R.C.S., J 0a, Sloane-street. Henry $J_{A y}$, 50, Sloane-street.

Wimliam Dickinson, 37, Sloane-street.

Alried Ford, Surgeon, Ebury street.

P.J. Murphy, 112, Sloane-street.

Martindale Ward, M.R.C.S., 140, Sloane-street.

S. J. Boulter, M.R.C S., 16, King's-road East.

John Coates, M.R.C.S., King's-road East.

Frederick Gaskeld, M.R.C.S., Markham-square.

A. B. Barnes, M.R.C.S., King's-road.

George Rambone, F.R.C.S., King's-road.

M. W. Sannemann, M.R.C.S., 15, Cheyne-walk.

John Wilkinson, Surgeon, Oakley-square.

Caarlas Sinpson, M.D., 5, Eccleston-street South.

Edward Davis, M.R.C.S., \&c., Upper Belgrave-place." 